\title{
A Comparative Analysis of Thai Bird's Nest Export to Chinese Market
}

\author{
Jintaporn Tangjitmanngamkul ${ }^{1}$ \\ 1. School of Economics, Shanghai University, 99 Shangda Road, Baoshan District, Shanghai City, China \\ *E-mail of the corresponding author: caramella.crml@gmail.com
}

\begin{abstract}
This study aims to explore the market situation of edible bird's nest both in Thailand and export situation. From the market exploring would support researcher to understand the factors that would affect to the market. Researcher plan to collect data from secondary data source, which would come from literature review from electronic databases. Researcher identifies the dependent variable and independent variable that would be studied in this study. The ultimate results that would be interested in the study is competitive index and competitive factors that could affect edible bird's nest market. The dependent variables are competitive indicator which is Revealed Comparative Advantage Index (RCA). The factors that could affect the dependent variables would be defined as independent variables. This study determines five independent variables which are Gross domestic product (GDP), Population, Thai Baht - Chinese Yuan Exchange rate, Fuel's price and Bird's nest price.
\end{abstract}

Keywords: Bird's nest, Competitive, China market

DOI: $10.7176 / \mathrm{EJBM} / 11-13-08$

Publication date:May $31^{\text {st }} 2019$

\section{Introduction}

International trade is very important for Nation's economy through importation and exportation. This mechanism is also true in Thailand. The exports trading market is one of the main Thai income channels. Normally, Thailand import raw material product to create to finished product. These finished products would be exported to gain the revenue to country. The efficiency of importation would increase the quality of finished product and increase the efficiency of exported competition. Thailand usually exports the electronic product, jewelry, automotive components, and natural processing products. The edible bird's nest is one of the high value export products from Thailand.

China is the most important international trade of bird's nest of Thailand. China is $90 \%$ of consumer in the bird's nest market. Bird's nest is rich people's food. In the other word, bird's nest is kind of food which indicate the socioeconomic of the consumer. The consumed rate of bird's nest is continuously increased in China. Normally, China imported bird's nest from 3 main countries that are Thailand, Indonesia and Malaysia. Thai bird's nest seems to be more popular among Chinese when comparing to the other two countries. The bird's nest from Thailand is high quality product. The quality of bird's nest is considered from many factors which are its texture, the softness and melting attribute. However, the bird's nest is a rare commodity. Because of the limited volume, bird's nest is considered as high value and expensive goods in the Southwest Asia. Thailand is one of the world's first nesting habitats, especially in southern Thailand.

Since bird's nest is considered as the health food and value gift for a long time. While, Thailand is one of the nature resources of bird's nest in South-East Asia. Researcher found that the exported potential of bird's nest in Thailand is the interesting issue to study. The results of the study will be benefit and for guiding private sector to develop the product and export strategies.

\section{Overview of Thai bird's nest export to Chinese market}

The Volume of bird's nest business in Southeast Asia is mass. The value of bird's nest market is average about 100 billion Baht per year. The Quantity of the bird's nest that is traded is around 2,800 tons per year. China is the world's largest consumer of birds' nests, accounting for more than 90 percent of the market. There are a few countries in the Southeast Asia that can produce the bird's nest and export to the demanded market. These countries are Indonesia, Malaysia, Thailand, Philippines, and Vietnam. Indonesia is the biggest source of bird's nest in Southeast Asia. Indonesia exports bird's nest around 2,000 tons per year, followed by Malaysia with 600 tons. The exported volume of the bird's nest of Thailand is about the third range compare with other country. 
Philippines is the smallest producer. Philippines exports the bird's nest around 5 tons per year.

In Thailand, trade value is estimated at around 10 billion Baht per year, generated by 400 tons of output of edible nests. The Ministry of Commerce (MOC) of Thailand reported the exported value of bird's nest of Thailand between 2007-2014. Moreover, The Ministry of Commerce (MOC) of Thailand also exports the total export values of Thailand between 2007-2017. The information is shown below.

From Table 1, the author could explain that the exported value of the bird's nest of Thailand continuously increase since 2007. The exported value of the bird's nest is maximum in 2011 as 8.45 million US dollars. Then the exported value decreased around 7 million US dollars. The decreasing of the exported value could be because the traded barrier policy from China in 2011-2012. China announced bird's nest imported prohibition. The prohibition is announced because of the Nitrate detection in the bird's nest. However, China agreed to allow the bird's nest importation again in 2015. The bird's nest exported valued of Thailand is raising again from 2.85 million US dollars in 2014 to 5.28 million US dollars. The exported value increased about two times comparing within one year. When the author considers the trend of the total exported value of Thailand, the author found that the total exported value of Thailand is constantly statistic. The table 1 shows that the difference of bird's nest exported value didn't affect the total exported value.

Table 1: Bird's nest value from Thailand and the total exported value of Thailand between 2007-2017.

\begin{tabular}{|l|l|l|}
\hline Year & Exported value (Million US dollars) & Total Exported value (Million US dollars) \\
\hline 2007 & 1.45 & $153,865.00$ \\
\hline 2008 & 3.07 & $177,755.20$ \\
\hline 2009 & 5.47 & $152,426.50$ \\
\hline 2010 & 8.60 & $193,298.10$ \\
\hline 2011 & 8.45 & $222,579.00$ \\
\hline 2012 & 1.90 & $229,084.30$ \\
\hline 2013 & 4.01 & $228,498.50$ \\
\hline 2014 & 2.85 & $227,462.00$ \\
\hline 2015 & 5.28 & $214,309.60$ \\
\hline 2016 & 4.51 & $215,387.50$ \\
\hline 2017 & 4.67 & $236,634.70$ \\
\hline
\end{tabular}

(Source: The Ministry of Commerce (MOC) of Thailand)

Table 2: The bird's nest exported value of countries between 2013-2017

\begin{tabular}{|l|l|l|l|l|l|}
\hline & 2013 & 2014 & 2015 & 2016 & 2017 \\
\hline Indonesia & 153.38 & 128.37 & 100.23 & 192.57 & 280.59 \\
\hline Malaysia & 8.25 & 18.78 & 27.70 & 46.71 & 63.23 \\
\hline Thailand & 6.06 & 4.69 & 5.28 & 4.51 & 4.67 \\
\hline Vietnam & 5.72 & 7.30 & 9.21 & 7.77 & 8.95 \\
\hline
\end{tabular}

(Source: the international trade statistic website)

\section{Revealed Comparative Advantage Index (RCA) analysis}

RCA analysis is the approximate tool that help to analyze and compare the exported competitive between countries. The RCA analysis is not complicated calculation. This index would show the competitiveness of that specialization of one product in the country.

The result of calculation is demonstrated as Table 3 below. The calculation shows that Thailand have RCA index 
below 1 from 2014 to nowadays. The ratio explain that Thailand do not advantage in bird's nest exportation to China. Indonesia and Malaysia have the index more than 1, which mean that these countries have advantage in the bird's nest exportation to China comparing to other countries in ASEAN.

Table 3: The RCA index from 2013 to 2017

\begin{tabular}{|l|l|l|l|l|}
\hline & Thailand & Indonesia & Malaysia & Vietnam \\
\hline 2013 & 1.52 & 2.25 & 1.24 & 0.27 \\
\hline 2014 & 0.00 & 0.00 & 5.25 & 0.00 \\
\hline 2015 & 0.02 & 4.60 & 2.72 & 0.00 \\
\hline 2016 & 0.04 & 4.82 & 2.56 & 0.00 \\
\hline 2017 & 0.02 & 5.73 & 1.86 & 0.00 \\
\hline
\end{tabular}

\section{Empirical Research}

From the RCA index analysis, researcher would collect the secondary data from Thai government database. This study would determine the independent variable that could affect the Bird's nest exportation situation in Thailand. There are four independent variable that author think could affect to the exportation are the Chinese GDP, and Chinese population. These China data would collect from World Domestic website. The other considers independent factor are the Baht - Chinese Yuan. The data would be collected from National Bank of Thailand. The last independent variable is the fuel's price, which would be collected from the Ministry of Energy of Thailand. There is one dependent variable is the RCA index. These independent and dependent variables would be analyzed to find the relationship.

Gross domestic product (GDP)

Gross Domestic Product (GDP) is the market value of all finished goods and services produced within one country in one year. It can describe the power of the buyer in one country. GDP is one of the important indicators that indicate the health of the one country's economy and the advance market move. Increases in GDP reflect economic growth of a nation. This study suggests the hypothesis that is the GDP should have a positive relationship with RCA. That means when the GDP increases, the amount of exportation should be also increased. The GDP data of China are collected from secondary data.

Population

There are many theories and evident those suggest that the size of population could reflect exportation. Some theory suggests that the population density could affect to the economic scale and affect to the comparative advantage of the exportation. In contrast, most of the studies also describe that the population would be the moderate variable. The statement means that the population is the variable that could affect the value of consumption by combining with other independent variables.

\section{Thai Baht - Chinese Yuan Exchange rate}

The exchange rate is one of the most significant factors in international trade. Normally, the exchange rate of currency could affect the trade surplus of deficit. Theoretically, the different of the currency exchange rate could affect the importation and exportation. If the exchange rate changes and affects that China could import goods cheaper, the import value could increase. This study collects and reports the China Yuan - Thai Baht. the result shoe that 1 Yuan equal approximate $4-5$ Baht. If the exchange rate decrease would affect to importation and exportation. The theory usually suggests that when the currency exchange rate decrease, which mean the goods would cheaper, the exportation would be better. So, the hypothesis would suggest that the RCA would have positive relationship with the exchange rate.

Fuel's price

Fuel price is one of the most significant factors on exportation, because the fuel is a cost of exportation. Increasing or decreasing of fuel cost would directly affect the cost of the transportation of the product and affect the product price. Thailand is one of the countries that imports oil from the international market. Because of the fuel's price would be the most part, the hypothesis suggest that the RCA index would have negative relationship with fuel' price variable. 


\section{Bird's nest's price}

There are studies that suggested the ideas of product price relationship with the export performance. Few studies are described in this study. (Katepan, Makhora, \&Mankeb, 2012) studied to identify the factors that influence the Okra exportation by using Porter's Diamond model. The study identified 84 factors that could affect the Okra exportation from Thailand to Japan. One of the most powerful factors is the product price itself. The study suggests that the product price could be the important factor that makes the buyer to make up their mind. (Jelodarloo, Hatami, \&Hatami, 2013) studied the relationship between four independent factors with export performance. The study used one company data as the case study to prove the marketing strategy. The company, which is used as the case study is Tabriz. Researchers used Pearson correlation coefficient to prove the relationship between four independent factors with the export performance as the dependent factor. The four independent factors are product adaptation, Price adaptation, Distribution adaptation and promotion adaptation. The study found that product adaptation and product price are two factors that relate with export performance the most. (Dolatabadi, Forghani, Tabatabaee, \&Faghani, 2013) did the research to examine effect of marketing framework on Iranian Protein export performance. The study identified four marketing independent factor as price, product, promotion, and place. These factors are identified as independent factors. These factors were proved relationship with export performance as the independent factor. Researchers used questionnaire data as the data to analyses in the study. Researchers suggested that these four independent factors would relate to dependent factors through the marketing strategy and then affected to the export performance. The study result showed that product pricing, and place relate with the export performance on Iranian protein product.

Theses researches suggest similar results which suggest that the product price could relate to export performance. The studies suggest that product price would have negative relationship with the export performance. When product price increase, the export performance would depreciate. In case of, the product price decreases the export performance would be increase. In this study, researcher expects the similar effect from the correlation analysis. The study hypothesis in this study would suggest that the bird's nest price would have negative relationship with the RCA index.

\section{The regression analysis model}

Table5: Econometric model analysis

\begin{tabular}{|c|c|c|c|c|c|c|}
\hline & $\log$ GDP & $\log$ population & $\begin{array}{l}\text { log Exchange } \\
\text { rate }\end{array}$ & $\log$ Fuel price & $\begin{array}{l}\text { log Bird's nest } \\
\text { price }\end{array}$ & $\mathrm{R}^{2}$ \\
\hline Model 1 & 70.11 & 23.25 & 0.01 & 22.54 & 6.82 & 0.9990 \\
\hline Model 2 & 409.86 & - $\quad 4,761.38$ & $\begin{array}{l}- \\
334.24\end{array}$ & 81.58 & & 0.9970 \\
\hline Model 3 & - 77.20 & & & & 7.09 & 0.8816 \\
\hline Model 4 & & 49.27 & 11.10 & $-\quad 214.83$ & & 0.6848 \\
\hline Model 5 & -18.52 & & 35.92 & 7.55 & & 0.6550 \\
\hline Model 6 & - 51.00 & 376.26 & 10.44 & & & 0.5897 \\
\hline Model 7 & - 61.21 & 469.21 & & & & 0.5741 \\
\hline Model 8 & -12.41 & & 27.46 & & & 0.4864 \\
\hline Model 9 & & & 39.78 & 7.01 & $\begin{array}{l}- \\
1.34\end{array}$ & 0.4458 \\
\hline Model 10 & & 94.13 & 33.23 & & & 0.4191 \\
\hline Model 11 & -19.65 & & & 4.58 & & 0.3735 \\
\hline Model 12 & & & 38.45 & 2.70 & & 0.3269 \\
\hline Model 13 & -15.38 & & & & & 0.3051 \\
\hline Model 14 & & & 34.24 & & & 0.2995 \\
\hline Model 15 & & 149.43 & & 4.35 & & 0.1884 \\
\hline
\end{tabular}




\begin{tabular}{|l|l|l|l|l|l|l|}
\hline & log GDP & log population & $\begin{array}{l}\text { log Exchange } \\
\text { rate }\end{array}$ & log Fuel price & $\begin{array}{l}\text { log Bird's nest } \\
\text { price }\end{array}$ & $\mathrm{R}^{2}$ \\
\hline Model 16 & & -100.86 & & & & 0.1375 \\
\hline Model 17 & & & & & - & 0.84 \\
\hline Model 18 & & & & 0.81 & & 0.0767 \\
\hline
\end{tabular}

(use regression analysis method, calculate by the author)

The Ordinary Least Square Test show 18 model of the regression analysis model. The test would indicate the variable that affects the exportation of Bird's nest the most. The test show that the GDP variable is the most influenced factor that affect the RCA index. The result from the model analysis concludes the fact that all models are reliable. There are five variables that consider as independent variable. The more factors add to the model the more $\mathrm{R}$ square. The regression model suggests the relationship between the independent variable and dependent variable. The exchange rate of the GDP of China, currency exchange rate and bird's nest price have the positive relationship with the exportation of swallow bird's nest from Thailand. The population size and the Fuel's cost have negative relationship with the exportation of swallow bird's nest from Thailand. These results mean that if the exchange rate increasing the export performance would also be increased. If the Fuel's cost of the logistic part is increasing the RCA would be decreased. The function of a regression model was a log-log model for analyzing the Ordinary Least Square. This data which are calculate show between 2007-2017. The analysis was for the two countries of Thailand and China.

The result from the regression analysis would be shown below.

$\log (\mathrm{RCA})=1,113+70.11 * \log \mathrm{GDP}+(-23.25 * \log$ Population $)+0.01 * \log$ exchange rate $+(-22.54 * \log$ Fuel price) $+6.82 * \log$ Bird's nest price $\mathrm{R} 2=0.9990$

The result from the model analysis concludes the fact that all models is reliable. There are four variables that consider as independent variable. The more factors add to the model the more $\mathrm{R}$ square. The regression model suggests the relationship between the independent variable and dependent variable. The GDP of China factor and the exchange rate of currency factor have the positive relationship with the exportation of swallow bird's nest from Thailand. The population size and the Fuel's cost have negative relationship with the exportation of swallow bird's nest from Thailand.

\section{Conclusion and Suggestion}

The situation of swiftlet bird's nest market is collected and shown that there are increasing demands of edible bird's nest inside and outside Thailand, especially in China. There are specific characteristics of the resource of the bird's nest in the nature. The swiftlet usually evacuates from Siberia to southern lands, which are Thailand, Vietnam, Indonesia, Malaysia, and other countries in South - East Asia. The swiftlet naturally builds the nest in the suitable atmosphere in the caves. The countries which have the similar geographic would be the nature resource of the swiftlet bird's nest. This research compares the competitive of the bird's nest exportation between these countries, which consists the swiftlet's bird's nest as the countries' resources. These countries are Thailand, Vietnam, Indonesia, and Malaysia. These countries have exported the bird's nest to China for a long time. However, China government detects the high volume of Nitrite in the bird's nest from Malaysia. Because of the event, AQSIQ (General Administration of Quality Supervision, Inspection and Quarantine of the People's Republic of China) has inhibited the swiftlet bird's nest import from foreign since 2011. There are many protocol and standard setting between the exported countries and China. China agrees to import the swiftlet bird's nest again in 2017. This study compares the competitive of exportation by using the RCA index. The RCA indexes are calculated from the equation to compare the ratio of bird's nest exported value with total exported value from candidate countries to China with the ratio of ASEAN countries. The RCA index in this study would express the comparative advantage of bird's nest exportation of the candidate country with ASEAN. The study calculates the RCA index from online database which provide information between 2013-2017, the results are shown in Table 3 .

The RCA index shows that Indonesia and Malaysia have RCA index more than 1 most of the time. This would indicate that in ASEAN, Indonesia and Malaysia have advantage in edible bird's nest exportation in ASEAN. However, consider the timeframe would show that Malaysia have RCA index more than 1 most of the time. The 
highest index is showed in 2014. Indonesia have RCA index increasing every year from 2014-2017. In the other hand, Thailand have RCA index of bird's nest exportation in 2013, after that Thailand have RCA index less than 1. Thailand still need to improve situation and supporting factor to improve the bird's nest exported situation. Thailand could study the limitation of government policy and legislation. Thailand should also study the exportation strategies from Indonesia and Malaysia to compare the situation and strength and weakness point of the industrial. Unfortunately, there are limited information of exported valued of Vietnam, so this study couldn't have enough information to discuss about Vietnam.

From the literature review, this study found that one of the big limitations of the bird's nest exportation from Thailand is Thai legislation itself. The Wildlife Preservation and Protection Act (1992) and the registered concession entrepreneurs is leading the effect to the bird's nest trade situation. There are both positive and negative results from the laws. One of the positive consequences of the law is that Thai government could carefully verify the industrial to reduce the bad result from the industrial. Thai government considers that the bird's nest businesses areas limitation could reduce the environment consequences. The environment consequences could be divided into two categories. The first one is the natural environment. The Thai government limits and registers the allowed entrepreneurs to control the balance of the natural bird's nest resources. The government could set the amount of the entrepreneurs to balance the resources. If there is low amount of the bird's nest, the government could announce to reduce the bird's nest concession. In addition, in case of the nature environment is destroyed by the bird's nest collection, the government could recently detect and recommend the strategies to deal with the environment situation. Another positive consequence of the bird's nest concession is the quality of the bird's nest from Thailand. The concession would limit the number of entrepreneurs in the business. The limit entrepreneur can be investigated and coached to farm, collect and process the bird's nest follow the quality standard ideally. The concession is also advantage to the government. The government could rate the tax or fee from the entrepreneurs. The fee and tax could return to develop and conserve the nature or environment. The tax also could be the fund to support the researched to improve the efficiency of the industrial. However, there are still the gaps of current situation, which determine the registered entrepreneur with concession allowing. The limit number of entrepreneurs in the high demanded market could affect individual to proceed the business of the record. There are many gaps in the system, so the official could not investigate all the entrepreneurs. In case of the entrepreneurs aren't allowed to do the concession, they would do the business underground. The underground business means that the government couldn't control the environment, the product quality. The government also could lose the benefit of the concession fees.

The RCA index would suggest the efficiency of bird's nest exportation of the specific country. This study would like to find the relationship between the factors that could be related to the exported efficiency. These factors are GDPs of the consumer's country (China), the population of China, the currency exchanged rate, and the fuel's cost. Researcher uses Ordinary Least Square (OLS.) to calculate the relationship between these variables. The factors that assume to affect the RCA index are categorized as independent variables. The RCA index is categorized as the dependent variable. The analysis suggests the equation as

$\log (\mathrm{RCA})=1,113+70.11 * \log \mathrm{GDP}+(-23.25 * \log$ Population $)+0.01 * \log$ exchange rate $+(-22.54 * \log$ Fuel price) $+6.82 * \log$ Bird's nest price $\mathbf{R 2}=\mathbf{0 . 9 9 9 0}$

The result from the model analysis concludes the fact that all models are reliable. There are five variables that consider as independent variable. The more factors add to the model the more $\mathrm{R}$ square. The regression model suggests the relationship between the independent variable and dependent variable. The exchange rate of the GDP of China, currency exchange rate and bird's nest price have the positive relationship with the exportation of swallow bird's nest from Thailand. The population size and the Fuel's cost have negative relationship with the exportation of swallow bird's nest from Thailand. These results mean that if the exchange rate increasing the export performance would also be increased. If the Fuel's cost of the logistic part is increasing the RCA would be decreased. The literature review suggests that the population sometime affect to the demand of the service and goods, which means that the higher population could have more demand in some basic service and goods. Furthermore, the market strategies, the product price could also affect the demand of the products. Considering bird's nest as the luxury goods, which is the product that beyond basic of the life, the population variable may not affect directly with the RCA. The future study should find the relationship or more mechanism about the population size and demand and the importation/ exportation.

Thailand is one of the resources of the swiftlets bird's nest. However, there are other neighbor countries that could collect and produce the bird's nest. This study collects the exportation value of the bird's nest from Thailand to China. The data is calculated and present in RCA index compare the bird's nest exportation competitive efficiency with other countries. The result suggests that Thailand still have the room to improve. The 
study would like to recommend two aspects of the Thai bird's nest exportation. The first aspect is about the improving the Thai bird's nest industrial. Thai decision makers should consider modifying the bird's nest concession policy. Nowadays, Thailand allows limited and registered entrepreneur to proceed the bird's nest business. This approach shows the strength points but there also are many flaws. There are some entrepreneurs do the business without permission. The under-report business could lead many negative results, which are the uncontrolled environment, uncontrolled product standard, the under rate of concession fee. Thai government should consider rearranging the bird's nest industrial concession. The openly business policy could support officers to control and organize the entrepreneurs. Furthermore, the concession fee could be collected more than present. The concession fee could help to support to reserve local resources. The fee could also manage and allocate to support the researches to improve the bird's nest industrial efficiency. Then Thailand could promote that Thai have high quality and standard bird's nest. The bird's nest business can be more efficiency and sustainable. The sustainable industrial which affect to local people would raise the quality of life. The second aspect is the international market policy. Thai government should plan to support bird's nest exportation through the market plan. This study and other studies suggest that the market policy, market strategies, and the market price setting affect to the luxury goods demand. Thai government should plan the strategies to support the Thai bird's nest to be higher level of competition. The market strategies could be the bird's nest price setting at the appropriate rate. The government also supports the industrial by promoting the Thai bird's nest. After the legislation modifying, the government could promote Thai bird's nest as the best-valued bird's nest in the South - East Asia.

\section{References:}

1. Dooksukkeaw, S. (2010). Opportunity of bird's nest international market in Rassia. SookkhoThaiThammathiRaj, 12.

2. Pupphavesa, W. (2008). Toward A Competitive ASEAN Single Market: Sectoral Analysis. Thailand Development Research Institute; TDRI. Retrieved December 18, 2018.

3. J., \& Mohan, R. (2005). International Marketing. Oxford University Press.

4. Kitkha, I., Thamjareum, Y., \&Pongwichai, S. (n.d.). Purchasing Behavior of Consumer on Swiftlet Nest's Product in Thailand. The 5th STOU Graduate Research Conference.

5. Marketing Insider. (2016, June 04). The Porter Diamond Model - National Competitiveness.

6. Thorburn, C. (2014). The Edible Birds' Nest Boom in Indonesia and South-east Asia: A Nested Political Ecology. Food Culture and Society an International Journal of Multidisciplinary Research, 17(4). doi:10.2752/175174414X14006746101439

7. Thorburn, C. C. (2015). The Edible Nest Swiftlet Industry in Southeast Asia: CapitalismMeets Commensalism. Human Ecology, 43(1). doi:10.1007/s10745-014-9713-1

8. Thailand Trading Report. (2018). Retrieved December 20, 2018

9. TIDTP. (2018). Retrieved December 22, 2018

10. Kenton, W. (2019, February 09). Gross Domestic Product - GDP.

11. Diacon, P. E., \& MAHA, L. G. (2015). The Relationship between Income, Consumption and GDP: A Time Series, Cross-Country Analysis. Procedia Economics and Finance, 23, 1535-1543. doi:10.1016/S22125671(15)00374-3

12. Anghelache, C., Marinescu, A. I., Avram, D., Burea, D., \& Bodo, G. (2017). Model analysis of the correlation between GDPand final consumption components. Romanian Statistical Review, 2, 84-95.

13. Amadeo, K. (n.d.). 10 Asian Powerhouses That Aren't China.

14. Lenaghan, N. (2017, April 07). The birds nest business: From Sumatra to Shenzen, via Melbourne.

15. NaturalnestThailand. (2015, December 12). The resources of the natural edible bird's nest.NaturalnestThailand.

16. Bakari, S., \&Mabrouki, M. (2016). The Relationship among Exports, Imports and Economic Growth in Turkey. Munich Personal RePEc Archive.

17. Ronit, M., \&Divya, P. (2014). The relationship between the growth of exports and growth of gross domestic product of India. International Journal of Business and Economics Research, 3(3), 135-139. doi: 
10.11648/j.ijber.20140303.13

18. The Edible Bird's Nest (EBN) society. (2017). Supply \& Demand of Bird's Nest.

19. YSC AGRO group BERHAD. (2017). YSC Swiftlet Farm Interest Scheme.

20. Yiran, Z. (2018, July 27). Bird's nest sales taking off.

21. Department of International Trade Promotion, Ministry of Commerce, Thailand; DITP. (2012). China announcement to inhibit the bird's nest importation. Retrieved December 25, 2018.

22. Prachachat News. (2017, September 05). China allows to import bird's nest from Thailand after the 5 years ban.

23. Star Media Group Berhad,. (2018, March 25). Wee: Govt to monitor birds' nest production.

24. Promwan, S., \&Rodjan, J. (2012). Legislation issues of the bird's nest entrepreneurs who is not allow in the concession in Thailand. Dhurakij Pundit University, 5(1). Retrieved December 25, 2018.

25. Viruhpintu, S., Thirakhupt, K., Pradatsundarasar, A., \&Poonnswad, P. (2002). Nest-site Characteristics of the Edible-nest Swiftlet Aerodramusfuciphagus (Thunberg, 1812) at Si-Ha Islands, Phattalung Province, Thailand. The Natural History Journal of Chulalongkorn University, 2(2), 31-35.

26. Boswall, J. and S. Kanwanich. 1978. The birds of Phi Phi Le Island, Krabi, Thailand. Nat. Hist. Bull. Siam Soc. 27: 83-92.

27. Wong, Z., Chan, G., Lam, H., Yao, P., Wu, L., \& Dong, T. (2018). A comprehensive proteomics study on edible bird's nest using new monoclonal antibody approach and application in quality control. Journal of Food Composition and Analysis, 66, 145-151. doi:10.1016/j.jfca.2017.12.014

28. Ratanakul, T. (2018, October 02). Bird's nest business survey and industrial evolution in Thailand.

29. Bangkok Entertainment Co.,Ltd.. (2018, September 24). Suggestion issue to the government to allow Swiftlet farming.

30. RYT9 News. (2017, October 6). The illegal Swiftlet farms. Retrieved December 26, 2018.

31. Prince of Songkla University. (2010, November 12). Low cost Swiftlet farm research. Retrieved December 26, 2018.

32. Ministry of Science and Technology; MOST. (2016, September). Edible bird's nest.

33. University of Delhi. (n.d.). The market Forces: Demand and Supply. In Microeconomics I: For University of Delhi. University of Delhi.

34. Y, L. (1996). Impact of population size on market demand under a market economy. Chin J Popul Sci., 8(2).

35. Kramer, L. (2019, February 27). Interesting Facts About Imports and Exports.

36. Alotaibi, K. (2016). How Exchange Rate Influence a Country's Import and Export. International Journal of Scientific \& Engineering Research, 7(5). Retrieved December 25, 2018.

37. Zakaria, Z. (2013). The relationship between export and exchange rate volatility: Empirical evidence based on trade between Malaysia and its major trading partners. Journal of Emerging Issues in Economics, Finance and Banking (JEIEFB), 2(2).

38. Ngondo, M., \&Khobai, H. (2018). The impact of exchange rate on exports in South Africa. Nelson Mandela University.

39. Sandu, C., \&Ghib, N. (2011). The relationship between exchange rate and exports in romania using a vector auto regressive model. Annales Universitatis Apulensis Series Oeconomica, 13(2).

40. Delaney, L. (2018). What to Think About for an Export Marketing Plan.

41. Western NIS Enterprise Fund. (n.d.). Export promotion policy.

42. Praisakuldecha, O. (2017). The economic strategic cooperation between China -Thailand under the ASEAN-China Free Trade Area (ACFTA). In case of the situation between China -Thailand and the opportunities of Thailand after ACFTA completed. IOSR Journal of Business and Management, 19(5). doi:10.9790/487X-1905052227

43. Manarungsan, S. (2001). Thailand - China Cooperation in Trade, Investment and official development assistance. 
44. Manprasert, S., Ph.D. (n.d.). CHAPTER 3: Overview of Thai economics. In Thailand economics and trade.

45. Katepan, P., Makhora, T., \&Mankeb, P. (2012). Factors Affecting Success for Exporting Thai OKRA (Abelmoschus esculentus L. Moench) in the World Market. King Mongkut's Agricultural Journal, 30(3), 112 .

46. Jelodarloo, S. N., Hatami, Z., \&Hatami, A. (2013). Impact of export marketing strategy on export performance (Case Study: Tabriz). International Journal of Management and Humanity Sciences, 2(6), 521529.

47. Dolatabadi, H. R., Forghani, M. H., Tabatabaee, S. M., \&Faghani, F. (2013). Effect of appropriate Marketing Mix Strategies on Iranian Protein Products Export Performance. International Journal of Academic Research in Accounting, Finance and Management Sciences, 3(3), 21-27. 